\title{
Trabalho voluntário e socialismo nos canaviais cubanos: uma história da safra de $1970 .^{1}$
}

\author{
Joana Salém Vasconcelos ${ }^{2}$
}

\begin{abstract}
Resumo: este artigo trata do papel do trabalho voluntário nos canaviais cubanos entre 1967 e 1970, na preparação para a chamada "safra gigante". No contexto dos debates sobre a transição socialista e das dificuldades econômicas impostas pela condição periférica, o trabalho voluntário nos canaviais figurou como solução aparente para dois problemas. Por um lado, supriria a escassez de mão de obra necessária para perseguir a meta de produção de 10 milhões de toneladas de açúcar. Por outro, representava um engajamento massivo da população na estratégia de "socialismo agrário" do governo, desenvolvendo novas relações sociais de produção, impulsionadas pela consciência dos trabalhadores. Buscaremos mostrar, entretanto, que o uso do trabalho voluntário ocultou contradições importantes da transição socialista na periferia, algumas das quais vieram à tona com o fracasso da safra. Além da pesquisa historiográfica, acessamos fontes orais (entrevistas com participantes da safra) e primárias (discursos políticos e relatórios oficiais).
\end{abstract}

Palavras-chave: Cuba; socialismo; trabalho voluntário; safra de 1970.

\section{Volunteer Work and Socialism in Cuban Sugar Cane Fields: a History of the 1970' Harvest}

Resumé: Cet article porte sur le rôle du travail volontaire dans les plantations de sucre cubaines en vue de la récolte de 1970. Dans le contexte des discussions sur la transition socialiste et des difficultés économiques originées par la condition périphérique, le travail volontaire dans les champs a figuré comme la solution apparente à deux problèmes. D'une part, il fournirait la main-d'œuvre nécessaire pour poursuivre l'objectif de produire 10 millions de tonnes de sucre. D'autre part, il représentait un engagement massif de la population dans la stratégie du «socialisme agraire »du gouvernement, amenant à les nouvelles relations sociales de production, potentialisées par la conscience des travailleurs. Cependant, le travail volontaire cache des contradictions de la transition socialiste dans la périphérie, dont quelques-unes ont émergé lors de l'échec de la récolte. Outre la recherche historiographique, nous accédons aux

\footnotetext{
1 Este artigo é parte da dissertação de mestrado defendida em 2013 no Programa de Pós-Graduação em Desenvolvimento Econômico do IE/UNICAMP, na área de História Econômica, cuja íntegra está disponível na biblioteca digital da UNICAMP. A pesquisa foi realizada com financiamento CAPES (5 meses) e FAPESP (19 meses). Todas as citações com bibliografia em espanhol ou inglês foram traduzidas para o português pela autora. 2 Historiadora (USP), Mestra em Desenvolvimento Econômico (IE/UNICAMP), Doutoranda em História Econômica (USP).
}

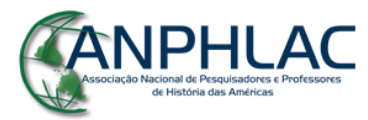

Revista Eletrônica da ANPHLAC, ISSN 1679-1061, Nº 21, p. 34-65, Jul./Dez., 2016.

http://revista.anphlac.org.br 
sources orales (interview avec les participants de la récolte) et primaires (discours politiques et rapports officiaux).

Mots-Clés: Cuba; socialisme; travail volontaire; récolte de 1970.

Artigo recebido em: 19/02/2016

Artigo aprovado para publicação em: 23/04/2016

\section{Introdução: os anos 1960 como um laboratório de estratégias}

Na década de 1960, no afã de edificar o socialismo, Cuba atravessou uma série de inflexões estratégicas, mudanças de paradigmas, replanejamentos, ajustes e autocríticas. Os experimentos cubanos ocorreram em meio a um turbilhão de debates sobre a transição, que alcançava escala mundial e pautava violentas disputas pelo poder e pela "linha do partido" na China, na URSS e no Leste Europeu. No contexto dos problemas histórico-estruturais especificamente cubanos, os dirigentes da revolução foram interlocutores destas amplas controvérsias, tanto quanto produziram seus próprios paradigmas. ${ }^{3}$

Em Cuba, as dúvidas a respeito dos caminhos a seguir, dos meios sociais, técnicos e econômicos da transformação socialista, fizeram da década de 1960 um verdadeiro laboratório de estratégias. Segundo Juan Valdés Paz (2012), sociólogo da Universidade de Havana e personagem da empreitada nos canaviais, a década de 1960 representa um dos períodos "mais autônomos" do projeto socialista cubano, sendo o trabalho voluntário uma das suas marcas. Muito embora os soviéticos tenham financiado as experiências desse laboratório desde cedo, suas políticas e inflexões foram conduzidas com base em decisões internas, forjadas nos marcos do debate agrário de 1961 e 1962 (VASCONCELOS, 2015) e do grande debate econômico de 1963 e 1964 (PERICÁS, 2004; VASCONCELOS, 2011). Isso só foi possível porque a súbita impulsão da ilha à condição de peça-chave da Guerra Fria lhe teria criado certa margem de

\footnotetext{
${ }^{3}$ Como, por exemplo, o Sistema Orçamentário de Financiamento proposto por Che Guevara (Pericás, 2004; Vasconcelos, 2011), bem como a ideia do socialismo do "homem novo" (Guevara, 2011).
}

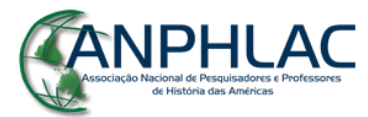

Revista Eletrônica da ANPHLAC, ISSN 1679-1061, Nº 21, p. 34-65, Jul./Dez., 2016.

http://revista.anphlac.org.br 
manobra, permitindo que os recursos soviéticos fluíssem sem que a doutrinação econômica se impusesse como contrapartida imediata. A essa configuração, o economista David Barkin (2011) nomeou "vantagens geopolíticas".

O período de 1967 a 1970 representou o último fôlego deste laboratório de estratégias, num esforço sem precedentes para superação de alguns obstáculos do subdesenvolvimento. ${ }^{4} \mathrm{~A}$ "ofensiva revolucionária", como foi chamado este triênio, caracterizou-se pela arrancada rumo à meta de produção de 10 milhões de toneladas de açúcar por meio da intensificação do controle estatal das unidades econômicas e da militarização da produção no campo. A safra gigante era o primeiro "salto" mais importante de uma estratégia paradoxal para o desenvolvimento das forças produtivas que intencionava superar a monocultura a partir da sua própria radicalização. Em outras palavras, segundo essa estratégia, o excedente da safra gigante viria a ser a alavanca da industrialização e diversificação da economia. Essa proposta foi identificada por Barkin como um modelo desequilibrado de crescimento ou "estratégia turnpike". 5

Nesse contexto, buscaremos mostrar que a política de trabalho voluntário nos canaviais cubanos foi fruto de uma dificuldade específica da transição socialista no capitalismo periférico latino-americano, destacando-se a contradição entre produtividade econômica e emancipação social. ${ }^{6} \mathrm{O}$ período investigado neste artigo corresponde a uma fase aguda desta contradição. O desafio naquele momento era equacionar a necessidade de aumento da produtividade com a emancipação social dos trabalhadores prometida pela revolução, partindo-se de uma base econômica que havia sido historicamente engrenada pela superexploração do trabalho. Como alcançar metas crescentes de produção e simultaneamente afrouxar a violência das relações sociais de trabalho no campo, garantindo a prometida melhoria do bem estar?

\footnotetext{
${ }^{4}$ Por subdesenvolvimento entendemos o processo de modernização das heranças coloniais da América Latina, que deu origem a estruturas produtivas alheias às necessidades da coletividade nacional, orientadas para o atendimento de demandas de economias estrangeiras e do consumo suntuário das elites internas (ver Sampaio Jr, 2000; Furtado, 1994).

${ }^{5}$ Turnpike são vias de tráfego rápido que percorrem uma distância mais longa do que a linha reta entre dois pontos, como um "rodoanel". Com esse termo, Barkin pretendeu definir um caminho específico de superação do subdesenvolvimento em Cuba, que seria simultaneamente mais longo e mais rápido que os ritmos do capitalismo central (ver Barkin, 1976, 1978).

${ }^{6}$ Por capitalismo periférico entendemos as formações históricas marcadas por heranças coloniais persistentes no contexto de uma divisão internacional do trabalho orientada pela modernização capitalista desigual e combinada. Entre tais heranças se encontram os altos níveis de desigualdade social, a superexploração do trabalho, a especialização primário-exportadora, a forte dependência econômica externa, instituições públicas com alto teor elitista e a violência cotidiana contra indígenas, negros e pobres. Para uma síntese teórica do desenvolvimento desigual e combinado do capitalismo periférico, ver Amin, 1976.
}

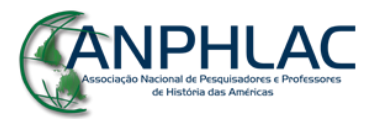

Revista Eletrônica da ANPHLAC, ISSN 1679-1061, №. 21, p. 34-65, Jul./Dez., 2016.

http://revista.anphlac.org.br 
Desde os primeiros anos da revolução, o trabalho voluntário foi incentivado diretamente pelos dirigentes, que fotografavam seus dias nos canaviais ou nas fábricas, suados e sujos pela experiência exemplar do “trabalhador comum”. Inspirados nos famosos Sábados Comunistas elogiados por Lênin, alguns dirigentes como Che Guevara inferiam que os trabalhadores voluntários eram os mais genuínos sujeitos históricos da nova economia, pois representariam o uso consciente da força de trabalho em prol de um projeto político coletivo. ${ }^{7}$ Nesse sentido, essa "nova relação social de produção" foi interpretada como a possibilidade de desalienação do trabalhador capitalista pela desmercantilização do trabalho.

Nos anos anteriores à safra de 1970, as brigadas voluntárias passaram a representar uma dimensão sem precedentes do trabalho coletivo do país. Tratava-se de, a um só tempo, produzir engajamento e excedente, diluir as fronteiras entre política e economia, cimentando as bases de uma nova cultura, que engendraria uma futura civilização. Idealmente, enfim, o trabalho voluntário poderia ser interpretado como a expressão do "homem novo" formulado por Guevara (2011), o trabalhador que encontraria na solidariedade e no coletivismo um sentido profundo para sua individualidade, empenhando seu tempo livre na edificação do bem comum. Mas, na prática, seu uso massificado na safra gigante representou problemas econômicos e políticos que serão abordados adiante. Em qual medida, enfim, o trabalho voluntário forjava simultaneamente novas relações sociais de produção, tanto quanto novas relações sociais de coerção?

\section{Trabalho voluntário como necessidade econômica}

O trabalho voluntário foi uma estratégia de mobilização política presente desde o início da revolução e institucionalizada durante a ofensiva revolucionária. Segundo Pericás, entre 1962 e 1967, o volume de trabalhadores voluntários cresceu de 15 mil para 70 mil, considerando tanto atividades urbanas como rurais (2004, p. 178). Embora esse processo acompanhasse um

\footnotetext{
${ }^{7}$ Sobre os Sábados Comunistas, Lênin escreveu: “O comunismo começa lá onde dos operários de base surge uma preocupação abnegada, que supera a dureza do trabalho, pelo aumento da produtividade do trabalho, pela salvaguarda de cada pud de trigo, de carvão, de ferro e de outros produtos que não se destinam pessoalmente aos que trabalham nem aos seus 'próximos', mas a pessoas 'alheias', isto é, a toda a sociedade no seu conjunto" (1980, p. 155).
}

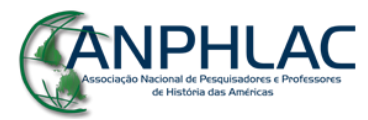

Revista Eletrônica da ANPHLAC, ISSN 1679-1061, №. 21, p. 34-65, Jul./Dez., 2016.

http://revista.anphlac.org.br 
discurso pelo fortalecimento das "alavancas morais" da economia, o trabalho voluntário foi também percebido como uma necessidade material, uma vez que às vésperas da safra de 1970 a mecanização do corte da cana estava frustrada e vivia-se uma escassez de cortadores profissionais.

Cuba enfrentava o pesado fardo da dependência tecnológica (FURTADO, 1981). Se no início o governo revolucionário formulou um ambicioso projeto de industrialização de bens de capital, rapidamente este foi redesenhado e adiado, de modo que a tarefa tecnológica imediata tornou-se a simples mecanização dos canaviais. ${ }^{8}$ Por uma série de características específicas da agrotecnia, as escolhas tecnológicas cubanas para mecanização da colheita possibilitadas pelo parque industrial soviético não surtiram os resultados desejados no tempo previsto. Em 1970, a meta do governo era uma colheita $30 \%$ mecanizada, quando a mecanização atingiu somente $1 \%$ da produção. Segundo Edquist, um dos principais motivos para o fracasso geral da mecanização do corte da cana na década de 1960 foi a escolha das cortadoras KTC soviéticas como foco prioritário de investimento $(1985$, p. 38, 127). A falta de capacidade técnica para operar a máquina e sua inadequação para o tipo de cana e a topografia da ilha fizeram com que, em 1965, somente $10 \%$ das máquinas compradas entrassem em atividade, proporção que se reduziu gradativamente até 1972, quando nenhuma delas foi utilizada. Os gastos feitos com essa escolha impediram que outras opções de mecanização tivessem sido testadas a tempo. Por isso, o salto estratégico programado para 1970 teria que ser perseguido por meio do trabalho humano vivo.

No entanto, surpreendentemente, Cuba atravessava uma situação de escassez de mão de obra nos canaviais. Como, afinal, um país com desemprego estrutural no tiempo muerto ${ }^{9}$ em 1958 chegou à situação de carência de braços para colheita dez anos depois? Isso se explica pela mudança do perfil de emprego na ilha. Entre 1959 e 1970, a redução do desemprego alcançou 90\%, chegando a uma taxa de apenas 1,3\% de desocupação (JUCEPLAN, 1971, p. 36). Esta queda do desemprego foi acompanhada de um deslocamento da força de trabalho dos canaviais para outras atividades produtivas. Diante de novas oportunidades de emprego e de

\footnotetext{
${ }^{8}$ Sobre o projeto guevarista de industrialização de Cuba, ver Pericás, 2004.

${ }^{9}$ Antes da revolução, tiempo muerto era o nome dado ao período da entressafra canavieira: durante oito meses ao ano, usualmente de abril a novembro, quase meio milhão de trabalhadores se tornavam desnecessários para o canavial, tendo que encontrar formas improvisadas de sobrevivência.
}

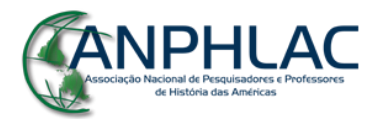

Revista Eletrônica da ANPHLAC, ISSN 1679-1061, №. 21, p. 34-65, Jul./Dez., 2016.

http://revista.anphlac.org.br 
estudo, muitos cortadores de cana migraram, optando por trabalhos menos pesados e mais bem remunerados, tendo muitos destes ingressado na escola pela primeira vez. Essa mudança no perfil de empregos está representada no gráfico 1.

GRÁFICO 1 - Mudança no perfil de emprego (1958-1971) (em índices, $1958=100)^{10}$

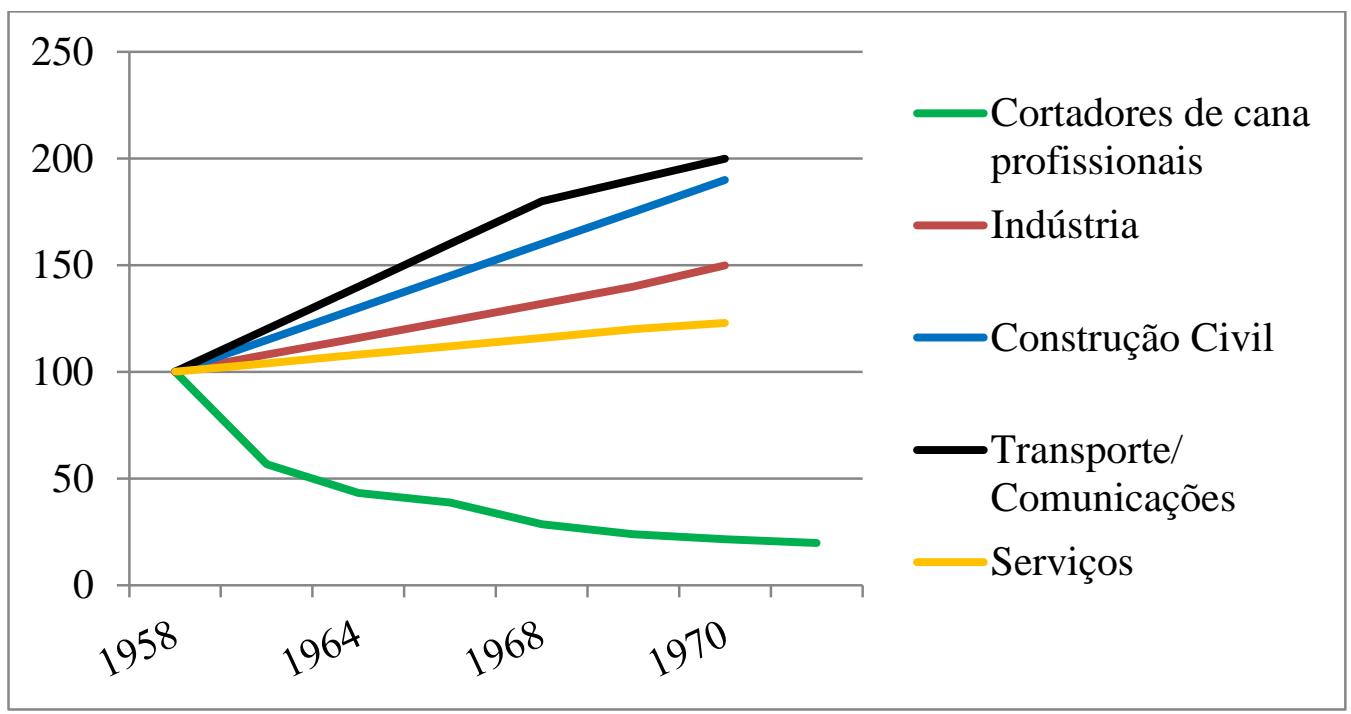

Era de se supor que, com o aumento da qualidade do emprego na ilha, os trabalhos mais pesados fossem abandonados. Haveria então uma necessidade econômica de recrutamento de braços para a safra gigante. As brigadas voluntárias passaram a ser recrutadas em todos os locais de trabalho, por meio de apelos políticos e morais. Numericamente, o recrutamento obteve sucesso: entre 60 e $65 \%$ da força de trabalho da safra de 1970 foi composta por voluntários (o que correspondia a cerca de 200.000 trabalhadores simultaneamente em ação). Apenas 20 a $25 \%$ dos cortadores eram profissionais e outros $20 \%$ eram membros das Forças Armadas Revolucionárias. Ao longo de toda a safra, entre julho de 1969 e julho de 1970, foram mobilizados 1,2 milhões de voluntários, provenientes das mais diversas províncias, profissões

\footnotetext{
${ }^{10}$ Edquist, 1985 , p. 35, 53, 99. Não estão incluídos os trabalhadores voluntários.
} 
e setores ${ }^{11}$. Uma radiografia da força de trabalho voluntário que participou da safra de 1970 pode ser vista na tabela 1 .

\begin{tabular}{|c|c|c|}
\hline \multicolumn{3}{|c}{ Fonte: Roca, 1976, p. 18-19, 46 } \\
\hline TABELA 1 - Trabalhadores da safra de 1970 & \% \\
\hline Profissional & Pessoas (ordem de grandeza) & $20-25$ \\
\hline Voluntário & 79.000 & $60-65$ \\
\hline Militar & 200.000 & $15-20$ \\
\hline Total no pico da safra & 71.000 & 100 \\
\hline Média trabalhador/ano & 350.000 & \\
\hline Total de voluntários & 250.000 & \\
\hline $\begin{array}{c}\text { Média trabalhador/ano suficiente para a } \\
\text { meta se todos fossem profissionais }\end{array}$ & 1.200 .000 & \\
\hline \multicolumn{2}{|c|}{70.0000} \\
\hline
\end{tabular}

Considerando que a força de trabalho cubana na década de 1960 era composta por aproximadamente 2,2 milhões de civis, os voluntários da safra de 1970 correspondiam a 54\% da mão de obra total do país. Posteriormente, calculou-se que se apenas cortadores profissionais trabalhassem na safra, seria preciso não mais que 70.000 trabalhadores/ano para atingir a meta, ou seja, apenas $28 \%$ da média de trabalhadores que estiveram ativos (ROCA, 1976, p. 18). As mobilizações de cortadores não profissionais lançou luz sobre a desqualificação do trabalhador voluntário, tema que será abordado mais adiante. Antes que isso fosse percebido, o trabalho voluntário foi alçado à condição de principal política para galvanização das massas em defesa do projeto revolucionário. A proposta dos estímulos morais e do voluntarismo como germe das novas relações sociais de produção, tese especialmente acalentada por Guevara, recolocou o problema da consciência política e da cultura no seio da economia.

\section{Trabalho voluntário como revolução cultural}

\footnotetext{
${ }^{11}$ Em 1967, a soma dos trabalhadores voluntários espalhados por todos os setores da economia alcançaria entre 200 e 300 mil, isto é, 8 a 12\% da mão de obra do país (Pericás, 2004, p. 179). Considerando apenas o setor agrícola, esse número quintuplicou na safra de 1970.
}

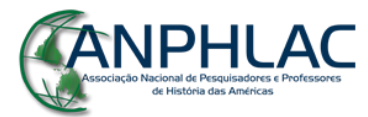

Revista Eletrônica da ANPHLAC, ISSN 1679-1061, Nº 21, p. 34-65, Jul./Dez., 2016.

http://revista.anphlac.org.br 
O que move um trabalhador ao trabalho na sociedade capitalista? A resposta a essa pergunta é complexa e não temos a pretensão de respondê-la, mas tão somente criar algumas balizas que nos levem ao problema do trabalho voluntário no socialismo cubano. Uma combinação dinâmica de fatores move o trabalhador ao trabalho, conforme o contexto social e histórico em que vivem. Dentre estes fatores, os mais essenciais e constantes estão ligados à sobrevivência imediata. Contudo, muitas outras camadas de fatores materiais e subjetivos se sobrepõem à mera sobrevivência.

As necessidades de bem estar, por exemplo, vão muito além da sobrevivência imediata e movem o trabalhador, uma vez que a proteção e o conforto oferecidos por uma moradia podem sempre ser mais sofisticados, a qualidade das vestimentas sempre pode melhorar e os alimentos serem mais abundantes. Existe, portanto, uma alta plasticidade daquilo que se compreende como sobrevivência imediata. O problema se complica ainda mais com a compreensão de Marx e Engels (1977) sobre a implacável vocação capitalista para produção constante de novas necessidades, novas mercadorias, novos fetiches, novos mercados, etc. Por "revolucionar-se a si mesmo", o capitalismo desenvolve aparências infinitamente diversas e criativas para a mesma essência. Nesse sentido, na sociedade capitalista, o trabalhador se move ao trabalho também em decorrência da promessa de satisfação destas novas necessidades, cada vez mais distantes da sobrevivência e diluídas entre o bem estar e o fetiche (MARX, 2006).

No caso das formações sociais periféricas, a presença do desemprego estrutural e de uma imperecível miséria cria a possibilidade da superexploração da força de trabalho, quebrando o poder de barganha da classe em seu conjunto. A necessidade da sobrevivência imediata e o medo de perder o emprego, de passar fome ou de sofrer castigos se tornam os sentimentos-motores do trabalhador periférico. No caso dos trabalhadores rurais cubanos dos anos 1950, a violência nas relações sociais de produção era flagrante, em decorrência do tiempo muerto e de uma herança escravista que fez do capataz do campo um pequeno tirano. ${ }^{12}$ Não à toa, essa violência foi um dos mais importantes alvos do processo revolucionário cubano que prometia uma nova vida aos trabalhadores rurais, isto é, terra, estabilidade salarial, menos brutalidade e mais bem estar. ${ }^{13}$ No entanto, quando a coerção capitalista deixou de ser o

\footnotetext{
12 Ver Vasconcelos, 2013, capítulo 1.

${ }^{13}$ Refletiu Fidel Castro, em $1^{\circ}$ de maio de 1971: "Qual era a lei do capitalismo para obrigar a trabalhar? O desemprego, a reserva laboral, a fome; a pistola no peito de cada trabalhador, de cada camponês. O camponês não
}

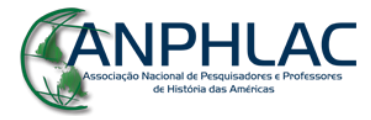

Revista Eletrônica da ANPHLAC, ISSN 1679-1061, №. 21, p. 34-65, Jul./Dez., 2016.

http://revista.anphlac.org.br 
oxigênio das relações sociais de produção, tornou-se necessário criar novos mecanismos que fizessem o trabalhador se mover ao trabalho.

Diante desse problema, inicia-se a polêmica dos estímulos materiais e/ou morais para incentivar o trabalhador. Entre 1961 e 1962, um debate agrário sobre a conversão das cooperativas canavieiras em granjas estatais contou com a participação de especialistas estrangeiros como Jacques Chonchol, Michel Gutelman e René Dumont, que se puseram de acordo na defesa da forma cooperativa de propriedade, entre outros motivos, por avaliar que o excedente privado retido em cada unidade produtiva seria um importante estímulo ao trabalho no campo, ao passo que o assalariamento estatal garantido poderia afrouxar a disciplina. Além disso, defendiam a correspondência entre horas trabalhadas e remuneração, garantindo o vínculo entre os ganhos individuais e o trabalho individual. Por outro lado, naquela ocasião, os dirigentes cubanos se puseram de acordo na defesa das granjas estatais, junto com a ampla maioria dos trabalhadores cooperativados que, no Congresso Nacional de Cooperativas em setembro de 1962, votaram em favor da mudança com 1.381 delegados favoráveis e apenas 3 contrários (FERNANDES, 2007, p. 186). Entre as alegações de Fidel Castro, estava precisamente o caráter mais igualitário do assalariamento estatal em relação aos ganhos diferenciados das cooperativas. A possibilidade de tais diferenciais era precisamente o que os especialistas externos apontavam como alavanca da produtividade do trabalho (VASCONCELOS, 2015).

Depois dessa inflexão, o grande debate econômico de 1963 e 1964 dividiu os líderes da revolução entre a predominância dos estímulos morais ou materiais na criação das novas relações sociais de produção (PERICÁS, 2004; GUEVARA, 2006). Por um lado, Carlos Rafael Rodriguez (então no comando do Instituto Nacional de Reforma Agrária) defendia, dentro do setor estatal, um programa de emulação socialista que envolvia a correspondência entre horas trabalhadas e salários, bem como um conjunto de incentivos materiais ao trabalhador. Tais estímulos consistiam em viagens nacionais e internacionais, casas, automóveis, motocicletas, geladeiras, entre outros benefícios de acordo com o cumprimento e a superação das metas. Por outro lado, Guevara foi o principal crítico dos incentivos materiais e defensor dos estímulos

tinha médico, não tinha educação, não tinha remédios, não tinha renda, não podia pagar arrendamentos”. (Castro, $1^{\circ}$ mai., 1971).

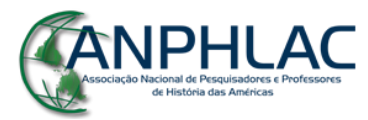

Revista Eletrônica da ANPHLAC, ISSN 1679-1061, №. 21, p. 34-65, Jul./Dez., 2016.

http://revista.anphlac.org.br 
morais para o aumento da produtividade. Na sua famosa formulação sobre o "homem novo", Guevara escreveu em carta ao amigo uruguaio Carlos Quijano:

\begin{abstract}
Perseguindo a quimera de realizar o socialismo com a ajuda das armas sujas que nos legou o capitalismo (a mercadoria como célula econômica, a rentabilidade, o benefício material individual como alavanca etc.), pode-se chegar num beco sem saída (...). Para construir o comunismo simultaneamente com sua base material, há que surgir o homem novo (GUEVARA, 2011, p. 229).
\end{abstract}

Guiado por esta ideia, quando esteve à frente do Ministério das Indústrias, Guevara promoveu eventos de entrega de incentivos morais aos trabalhadores que se destacavam na produção, tais como o "certificado do trabalhador comunista" para os que cumprissem 240 horas como voluntários. Para Guevara, o trabalho voluntário era a senda que levaria a sociedade cubana à superação da distância entre trabalho manual e intelectual, criando o caminho para a diluição das classes sociais em uma sociedade igualitária ${ }^{14}$ (GUEVARA, 1982).

Diante da discordância entre Guevara e Rodríguez, Fidel adotara uma postura intermediária e distante. No espírito do laboratório de estratégias, propôs a experimentação de cada um dos modelos nos seus respectivos comandos, da indústria e da agricultura, inaugurando uma situação de dualidade que predominou entre 1964 e 1966 (VALDÉS PAZ, 2009, p. 1819). Essa conciliação foi justificada por Fidel com o argumento da construção simultânea do socialismo e do comunismo. ${ }^{15}$

É certo que apenas $20 \%$ dos trabalhadores da ilha participaram do programa de emulação socialista de Rodríguez e, destes, apenas $1 \%$ a 1,7\% foram beneficiados. Ou seja, o efeito dos incentivos materiais sobre a produtividade do trabalho foi residual entre 1964 e 1966 (MESA-LAGO, 1971, p. 77). Suas dimensões não foram sequer comparáveis à emulação stakhanovista da URSS de 1935 e $1936 .^{16}$

\footnotetext{
${ }^{14}$ Para uma análise mais profunda do pensamento de Guevara sobre o trabalho voluntário e suas conexões com outras experiências socialistas, ver o capítulo 6, "O socialismo e o homem novo", do livro de Pericás (2004).

${ }^{15} \mathrm{Ou}$ seja, conviveriam, na transição cubana, as relações de produção que correspondessem ao socialismo, "a cada um segundo seu trabalho", ainda permeadas pela necessidade do incentivo material; e ao comunismo "a cada um segundo suas necessidades", já movidas pelo incentivo moral (Marx, 2005).

${ }^{16}$ Sobre a história de Stakhanov, o problema da produtividade e da organização do trabalho na União Soviética, ver Lucas, 2015.
}

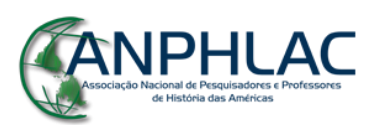

Revista Eletrônica da ANPHLAC, ISSN 1679-1061, №. 21, p. 34-65, Jul./Dez., 2016.

http://revista.anphlac.org.br 
Mas em 28 de setembro de 1966, um discurso de Fidel anunciou uma mudança de ventos e o fim da dualidade. Em tom acusatório, argumentou contra os estímulos materiais individuais e defendeu a priorização dos incentivos morais, inaugurando assim a chamada "ofensiva revolucionária":

\begin{abstract}
Nós temos que estimular no povo estes fatores de consciência, temos que estimular no povo os fatores morais, além do esforço por satisfazer suas necessidades materiais [...]. É preciso dizer que quem quer resolver o problema apelando ao egoísmo individual, apelando ao esforço individual de solução dos seus problemas, esquecidos da sociedade; quem fizer isso estará atuando de modo reacionário, estará conspirando - ainda que o faça com as melhores intenções do mundo - contra a possibilidade de criar no povo uma consciência verdadeiramente socialista, verdadeiramente comunista (CASTRO, 28 set., 1966).
\end{abstract}

A partir de então, o trabalho voluntário se tornou um componente estratégico de um processo de generalização das alavancas morais na economia. Desde 1967, surgiu um novo sistema de incentivos que premiava os trabalhadores mais produtivos com diplomas, flâmulas, a Bandeira do Moncada, medalhas ou títulos de honra, tais como o de "Trabalhador de Vanguarda", o de "Millonario" (referente às 10 milhões de toneladas), o de "Herói Nacional do Trabalho", entre outros. Outro estímulo moral era dado aos trabalhadores mais pobres cujos nomes foram atribuídos a lugares proeminentes, dando-lhes um prestígio nunca antes imaginado (MESA-LAGO, 1971, p. 82; BARKIN, 1978, p. 215; SILVERMAN, 1978, p. 165). Através destes incentivos morais, propunha-se que o trabalho fosse encarado como um dever social e não mais como um veículo de incremento do bem estar individual. Silverman sustentou que “a 'moralização do trabalho' substituiu os incentivos materiais como meio de modernização" (1978, p. 164). Ou seja, a "consciência revolucionária” deveria ser um motor da safra de 1970 e, portanto, da modernização econômica sobre a qual se desdobraria a estratégia turnpike.

Mas a opção pela economia moral não respondia somente à convicção política de Fidel Castro "despertada" em setembro de 1966. Haveria também uma conveniência material do sistema de incentivos morais. Conforme as políticas igualitaristas surtiam efeito, o aumento do poder de compra das massas não correspondia com a disponibilidade de bens de consumo. Por isso, por exemplo, as contas de poupança e a circulação monetária da ilha alcançaram a soma

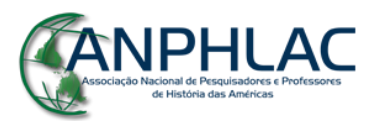

Revista Eletrônica da ANPHLAC, ISSN 1679-1061, №. 21, p. 34-65, Jul./Dez., 2016.

http://revista.anphlac.org.br 
de 3 bilhões de pesos, atingindo o mesmo valor do fundo de salários (CEPAL, 1980, p. 175). Salários estes, portanto, que perderam a capacidade de representar um estímulo material individual à produtividade. A moralização da economia e o trabalho voluntário, contudo, desencadearam consequências imprevistas e indesejadas para a própria safra de 1970.

\title{
Metas inalcançáveis e fracasso da safra de 1970
}

Selma Díaz foi dirigente do Instituto de Planificação Física do Ministério de Obras Públicas da década de 1960 e participou dos primeiros cálculos para avaliar qual seria a meta açucareira de 1970. Na safra, foi a dirigente responsável pela garantia das metas do Oriente, a região mais importante do país para a produção de açúcar. Em julho de 2010, Díaz relatou publicamente que em 1964 sua equipe chegara ao número de 8,4 milhões de toneladas, averiguando que o investimento necessário para 10 milhões não poderia ser cumprido em tempo hábil (VALDÉS PAZ et al., 2012, p. 71). A meta das 10 milhões, portanto, não nasceu do Instituto de Planificação.

Naquele ano, Selma enviou uma carta a Charles Bettelheim (ativo participante do grande debate econômico), na qual o alertava sobre a impossibilidade da safra de 10 milhões:

\begin{abstract}
Como sempre, pensou-se que, se éramos capazes de produzir nove milhões de toneladas em 1970, por que não dez em 1968? E agora a comissão ensaia retificar o plano, ajustá-lo às novas metas com a convicção de que não poderão fazê-lo. O INRA também ensaia cumprir seus planos com a convicção de que não os podia cumprir e assim até o infinito. E logo, nós ensaiamos demonstrar que não podemos seguir trabalhando desta maneira (SELMA DÍAZ apud VALDÉS PAZ et al., 2012, p. 70).
\end{abstract}

Qualificada tecnicamente para ocupar posição de quadro estratégico no governo e munida de relativo poder de decisão a respeito das metas, Selma estava convencida de que as 10 milhões não seriam atingidas, seis anos antes do revés se concretizar. A crítica indicava que o procedimento de traçar metas inalcançáveis não se restringia ao setor açucareiro e estaria se disseminando em vários setores. Neste sentido, todo o esquema de expectativas da estratégia turnpike se desmoronaria ao primeiro passo. Julio Travieso, economista cubano presente no debate de 2010 perguntou:

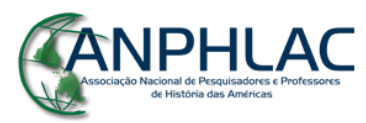

Revista Eletrônica da ANPHLAC, ISSN 1679-1061, Nº 21, p. 34-65, Jul./Dez., 2016.

http://revista.anphlac.org.br 
Minha pergunta é: por que 10 milhões? Se houvéssemos dito: 'vamos fazer a maior safra da nossa história', não haveria fracasso político, porque assim se deu. Então, por que 10? Por que não 11 ou 9,5? Qual é a explicação e de onde saiu este número que ao final levou ao fracasso político? (VALDÉS PAZ et al., 2012, p. 74)

\title{
Ao que Selma respondeu:
}

A cifra 10 milhões foi uma decisão pessoal do companheiro Fidel Castro. Nós discutimos com ele o trabalho que havíamos concluído na agricultura, a avaliação de cada uma das 154 centrais existentes, e que, segundo os resultados, poderíamos chegar, aproximadamente, aos 8,2 ou 8,3 milhões de toneladas. Propusemos-lhe 8,5 milhões. Na primeira reunião, ele nos disse: 9 milhões. E em 1964, de 9 se passou a 10 milhões e já esta meta era impossível. (VALDÉS PAZ et al., 2012, p. 75)

Juan Valdés Paz, que se tornou administrador agrícola no decorrer do processo revolucionário, confirmou o relato de Selma em entrevista conosco em 2012:

\begin{abstract}
Há aí uma história não contada. A cifra 10 milhões não estava sustentada em nada. Os estudos de campo nada mais que asseguravam cana para 8,75 milhões, quiçá 9 milhões. Quiçá. Muito difícil. E do ponto de vista econômico, todos os economistas que comentaram o tema, inclusive Bettelheim que estava em Cuba, disseram que a capacidade existente tornava racional uma projeção entre 8 e 8,5, mas que buscar 8,5 levava inversões suplementares que não se justificavam. [...] Tudo foi uma aposta que seguramente tinha por trás alguma lógica política, mas que havia perdido toda lógica econômica e o sentido de factibilidade, como se demonstrou (2012).
\end{abstract}

Ao mesmo tempo, um conjunto de outras metas para outros setores da economia foi batizado pelo governo de batalhas simultâneas. Em 1969, Fidel Castro chegou a afirmar que se a meta açucareira fosse atingida, mas as outras não o fossem, poderiam considerar-se derrotados: "a coisa mais importante é que nós não sacrifiquemos nenhum outro plano para atingirmos a meta açucareira. Essa seria nossa real vitória. Se for preciso parar todo o resto, não haverá vitória." (CASTRO apud ROCA, 1976, p. 12)

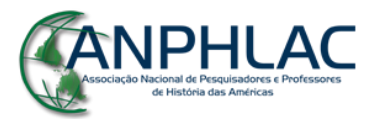

Revista Eletrônica da ANPHLAC, ISSN 1679-1061, №. 21, p. 34-65, Jul./Dez., 2016.

http://revista.anphlac.org.br 
Essa postura contribuiu para que o impacto da frustração fosse ainda mais intenso quando, em maio de 1970, o próprio Fidel anunciou que sequer as 10 milhões de toneladas seriam atingidas. Algumas destas outras metas estão expostas na tabela 2.

\begin{tabular}{|c|c|c|}
\hline \multicolumn{3}{|c|}{ TABELA 2 - Batalhas simultâneas (1968-1975) } \\
\hline Setor & Quantidade & Ano \\
\hline Investimento/PIB ${ }^{\mathrm{e}}$ & $31 \%$ & 1968 \\
\hline Açúcar & 10 milhões de toneladas & 1970 \\
\hline Café a & 83 mil toneladas & 1970 \\
\hline Peixe $^{c}$ & 151,5 mil toneladas & 1970 \\
\hline \multirow{2}{*}{ Gado } & 9 milhões de cabeças ${ }^{\text {a }}$ & 1970 \\
\hline & 12,5 milhões de cabeças ${ }^{\mathrm{e}}$ & 1975 \\
\hline Fertilizantes $^{c}$ & 1 milhão de toneladas & 1973 \\
\hline Cítricos b & 750 mil toneladas & 1975 \\
\hline $\operatorname{Arroz}^{\mathrm{e}}$ & Autossuficiência & 1975 \\
\hline Carne bovina $^{\mathrm{e}}$ & Autossuficiência & 1975 \\
\hline Leite $^{\mathrm{e}}$ & Autossuficiência & 1975 \\
\hline \multicolumn{3}{|c|}{$\begin{array}{l}\text { Fonte: }{ }^{\mathrm{a}} \text { Gutelman }(1975, \text { p. } 243,262),{ }^{\mathrm{b}} \text { Dumont }(1970, \text { p. } 225),{ }^{\mathrm{c}} \mathrm{FAO},(1966, \text { p. } 32),{ }^{\mathrm{d}} \text { Aranda } \\
\text { (1968, p. 28), }{ }^{\mathrm{e} B a r k i n}(1976, \text { p. } 124,127,130) \text {. } \\
\text { Observação: À autossuficiência planejada para carne bovina e leite em 1975, somar-se-iam } \\
10 \text { a } 15 \text { milhões de dólares de exportação na expectativa de geração de excedente. }\end{array}$} \\
\hline
\end{tabular}

Sergio Aranda escreveu em 1967 que para que a meta de 10 milhões fosse atingida, seria necessário ampliar a superfície canavieira em 25.000 caballerías ${ }^{17}$, aumentar os rendimentos industriais em 40\%, introduzir novas variedades de cana em 53.000 caballerías e cultivá-las com métodos mecanizados por no mínimo três anos (ARANDA, 1968, p. 60, 69). "Este conjunto de tarefas”, alegou Julio Díaz Vázquez, “introduziu uma tensão no país” (VALDÉS PAZ et al., 2012, p. 70). O sacrifício dos trabalhadores cubanos na busca por todas estas metas foi exemplificado pelo relato de Díaz:

${ }^{17}$ A caballería é uma medida de superfície usada em Cuba, que equivale a 13,42 hectares (Chonchol, 1961, p. 28).

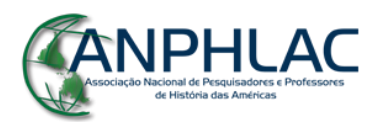

Revista Eletrônica da ANPHLAC, ISSN 1679-1061, №. 21, p. 34-65, Jul./Dez., 2016.

http://revista.anphlac.org.br 
No Oriente, fecharam-se os centros noturnos, não se podia comprar uma garrafa de rum em parte alguma. Quando estávamos em plena safra, tivemos que pedir permissão ao comandante Guillermo García, que estava dirigindo a província, para darmos algumas garrafas de rum aos que estavam cortando cana debaixo da chuva. (VALDÉS PAZ et al., 2012, p. 73)

Os trabalhos de corte de cana não paravam. A este relato de Selma Díaz, Gladys Marel García, da plateia, agregou: "Em Yaguajay, os camponeses tinham que semear a terra de noite, com faróis, para satisfazer sua alimentação" (VALDÉS PAZ et al., 2012, p. 74). Movidos pela confiança em Fidel Castro, pela própria consciência política ou pelo medo de perseguição, os cubanos (profissionais e voluntários) cortaram cana de 14 de julho de 1969 até 26 de julho de 1970, parando apenas para a manutenção das máquinas.

A safra de 1970 durou 217 dias, mais que o dobro da média de 102 dias das safras de 1951 a 1969. No entanto, apesar desse esforço coletivo descomunal em busca de um conjunto de metas dificilmente atingíveis, os anos de 1969 e 1970 apresentaram os piores rendimentos de toneladas de cana moída por dias de safra e bateram o recorde do mais baixo rendimento industrial (toneladas de açúcar/toneladas de cana) de uma série de 20 anos (JUCEPLAN, 1971, p. 136).

A distância entre o plano e a realidade da safra de 1970 está exposta na tabela 3.

\begin{tabular}{|c|c|c|}
\hline \multicolumn{3}{|c|}{ TABELA 3 - Plano e realidade da safra de 1970 } \\
\hline Superfície de cana (caballerías) & Plano & Realidade \\
\hline Toneladas de açúcar (milhões) & 115.000 & 114.351 \\
\hline Toneladas de cana colhida (milhões) & 81,4 & 8,35 \\
\hline Rendimento agrícola (tonelada cana/hectare) & 53 & 50,9 \\
\hline $\begin{array}{c}\text { Rendimento industrial } \\
\text { (tonelada açúcar/tonelada cana } * \mathbf{1 0 0})\end{array}$ & 12,3 & 10,71 \\
\hline Uso da capacidade industrial $(\%)$ & 90 & 67 \\
\hline Fonte: Roca, 1976, p. 15, 31. & \\
\hline
\end{tabular}

Num primeiro olhar, o maior estrangulador da cadeia produtiva de açúcar teria sido o setor industrial, cujos rendimentos ficaram 13\% abaixo das expectativas, com um uso da capacidade $25 \%$ menor do que o imaginado. Muitas análises da safra de 1970 concordaram a

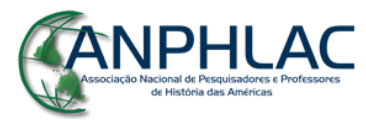

Revista Eletrônica da ANPHLAC, ISSN 1679-1061, Nº 21, p. 34-65, Jul./Dez., 2016.

http://revista.anphlac.org.br 
esse respeito. ${ }^{18}$ De fato, a crise da indústria se iniciou em dezembro de 1969 e se tornou incontornável em fevereiro de 1970. Muitas centrais açucareiras foram obrigadas a parar por problemas técnicos, relacionados à falta de peças de reposição e/ou necessidade de manutenção de maquinaria, obrigando a cana a viajar para centrais muito distantes. Esse problema se transformou na "crise de fevereiro", quando 23 centrais (de um total de 154) simplesmente pararam de funcionar, dentre as quais estavam $45 \%$ das unidades industriais mais produtivas da ilha. Durante algumas semanas, 30\% da capacidade industrial total da ilha estiveram completamente paralisadas. Isso gerou um desequilíbrio na cadeia açucareira devido ao excesso de cana em relação à capacidade industrial, fazendo com que 4 milhões de toneladas de cana cortada tivessem seus trajetos alterados (ROCA, 1976, p. 21-22, 28).

Assim, a paralisia industrial se propagou para o setor de transportes, que já operava em máxima capacidade. A partir de dezembro de 1969, os dois problemas se retroalimentaram porque quanto mais tempo a cana cortada demorou para ser processada, menor seu potencial açucareiro. O ideal era que a cana fosse moída em menos de 24 horas. Atingindo três dias de atraso, a cana plantada perdia $10 \%$ de seu rendimento e, com sete dias de atraso, a perda chegava a $25 \%$. Com a crise industrial, a média de tempo transcorrido entre o corte da cana e a indústria foi de três dias. Com a crise de fevereiro, essa média cresceu. Aparentemente, para atingir a rentabilidade industrial planejada, contava-se com um atraso zero, que a cana fosse cortada e processada no mesmo dia, o que de partida já era impossível (ROCA, 1976, p. 22).

Entretanto, parte da queda dos rendimentos industriais se deveu diretamente ao setor agrícola. Como vimos, a mecanização do corte não ocorreu no tempo previsto. Além disso, erros de planejamento das plantações fizeram com que canaviais fossem cortados com menos de 18 meses de vida, gerando uma massa canavieira de baixa concentração de açúcar. E, enfim, os erros cometidos pelos cortadores de cana, a maioria deles voluntários e inexperientes, foram

\footnotetext{
${ }^{18}$ Fidel Castro, em seu discurso de 19 de maio de 1970, admitiu: "Encontramos o problema dos rendimentos. Foi a dificuldade mais grave que encontramos, derivada dos investimentos industriais em primeiro lugar, e também dos problemas operacionais nas centrais" (Castro, 19 mai., 1970). Analistas estrangeiros e cubanos concordaram. Sergio Roca atribuiu $80 \%$ dos problemas operacionais ao setor industrial e às falhas de transporte (déficit de 1,2 milhões de toneladas) e $20 \%$ ao setor agrícola (déficit de 300.000 toneladas) (Roca, 1976, p. 20). Barkin pensava o mesmo: "um dos fatores fundamentais de estrangulamento foi a inadaptação da indústria, incapaz de tratar efetivamente toda a cana-de-açúcar aproveitável” (1978, p. 44). Julio Díaz Vasquéz também: “O que não houve foram as centrais. (...) A indústria não pôde assimilar o programa de desenvolvimento" (Valdés Paz et al., 2012, p. 71).
}

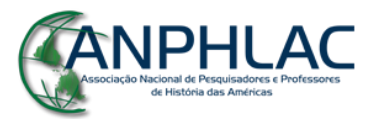

Revista Eletrônica da ANPHLAC, ISSN 1679-1061, №. 21, p. 34-65, Jul./Dez., 2016.

http://revista.anphlac.org.br 
determinantes (ROCA, 1976, p. 15-17). A queda da produtividade do trabalho agrícola se encontrava no cerne do problema da transição socialista nas sociedades periféricas.

\section{Eliminação do capataz e queda da produtividade}

Não por acaso, 1971 foi chamado o "ano da produtividade" em Cuba (SILVERMAN, 1978, p. 143). Embora o aproveitamento das capacidades produtivas anteriormente subutilizadas na ilha tenha viabilizado um considerável impulso inicial ao projeto revolucionário, mudanças desencadeadas pela própria revolução causaram uma forte queda da produtividade do trabalho, que contribuiu para o fracasso da safra de $1970 .{ }^{19}$

Uma pesquisa feita em 1963, por exemplo, revelava que nas granjas estatais os trabalhadores se dedicavam apenas 4 ou 5 horas por dia aos cultivos e ganhavam salários por uma jornada de 8 horas, uma vez que já não possuíam mais o antigo medo do desemprego e que os salários e as horas de trabalho foram repentinamente desvinculados (MESA-LAGO, 1971, p. 96). Mas a indisciplina laboral não era apenas uma consequência da falta de estímulos materiais individuais ao trabalho. Comprometida com algumas das suas promessas, a revolução eliminou do processo produtivo um personagem desagradável que, no entanto, era o fiador da disciplina do trabalho: o capataz.

Ao depender predominantemente de setores produtivos intensivos em trabalho, a sociedade periférica geraria riquezas na mesma medida em que fosse capaz de disciplinar o trabalhador, na maioria das vezes, em condições de extremo esforço físico e poucas recompensas. A contrapartida da transformação da agricultura cubana e da garantia de bem estar social à população rural era a dificuldade de disciplinar o trabalhador sem recorrer a métodos coercitivos (capitalistas ou não).

\footnotetext{
${ }^{19}$ Entre tais mudanças: (1) a fraca identificação de uma camada média de técnicos com a revolução desencadeou um êxodo de mão de obra qualificada; (2) o bloqueio estadunidense gerou escassez de peças de reposição e sucateamento da indústria açucareira e dos transportes; (3) a escassez de bens de consumo desestimulava o trabalhador ao trabalho; (4) para alguns analistas, como Mesa-Lago (1971), a priorização dos incentivos morais limitou a disciplina laboral e ampliou o absenteísmo. Enfim, o perfil de crescimento demográfico cubano caminhava para a redução da população economicamente ativa.
}

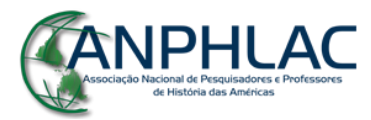

Revista Eletrônica da ANPHLAC, ISSN 1679-1061, №. 21, p. 34-65, Jul./Dez., 2016.

http://revista.anphlac.org.br 
Fidel Castro enfatizou, em seu discurso de autocrítica de 26 de julho de 1970, que o heroísmo do povo cubano residia no fato de que as motivações do trabalho já não eram mais o desespero e a pobreza, mas sim uma nova moral revolucionária. ${ }^{20}$ A história havia demonstrado que, apesar de heroicas, as novas motivações seriam ainda insuficientes para 10 milhões. Isso porque o capataz era um eficiente agente disciplinador do trabalho, cujas armas coercitivas eram diretamente proporcionais ao desemprego estrutural decorrente da plantation modernizada (VASCONCELOS, 2013, capítulo 1). Eliminado o capataz e o desemprego, nenhum outro organizador do trabalho poderia ser tão eficiente. Juan Valdés Paz, administrador nos canaviais, explicou-nos que

\begin{abstract}
Esse elo passou de explorador a nada, quando tinha que haver passado de explorador a alguém que cobrisse de alguma maneira tal função. Por isso, todos os esquemas, na agricultura nunca funcionaram. Nem materiais, nem morais, nem nenhum dos esquemas de organização do trabalho. Também a indústria se viu muito afetada, mas na indústria a máquina impõe um ritmo de trabalho que pode ser facilmente medido. Já na agricultura, como na construção civil, fixar normas de trabalho é difícil porque as condições são muito variáveis. (VALDÉZ PAZ, 2012)
\end{abstract}

As novas relações de produção agrárias engendraram uma nova contradição entre produção eficiente e emancipação social. O administrador da plantação canavieira deveria, através do convencimento, cumprir o papel de disciplinador do trabalho anteriormente cumprido pelo capataz através da violência. Mas este novo administrador agrícola, como o próprio Valdés Paz, não se identificava com a figura do explorador e não tinha nenhum interesse em entrar em conflito com os trabalhadores. Por isso, não se empenhava em controlar as normas técnicas de trabalho e evitava denunciar tarefas mal feitas. Ao invés de assumir uma postura de cobrança que pressionasse pelo aumento da produtividade, o administrador estabelecia normas médias de trabalho, que todos pudessem cumprir, e não verificava com rigor os resultados. Ademais, com os salários médios garantidos pelo Estado, o administrador tampouco detinha instrumentos efetivos de poder para pressionar os trabalhadores a executarem tarefas pesadas a céu aberto. Valdés Paz foi administrador agrícola durante 20 anos (de 1962 a

\footnotetext{
${ }^{20}$ Afirmou Fidel: "O povo foi herói não só na execução desse trabalho. Mais ainda quando se entregou até à última cana, apesar de saber que não se alcançariam as 10 milhões (...) As razões pelas quais os trabalhadores fazem esforços extraordinários não são as do passado, que eram a fome e a morte, mas a honra" (1980, p. 19-20).
}

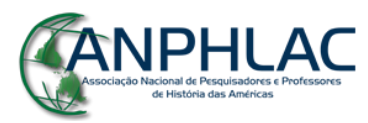

Revista Eletrônica da ANPHLAC, ISSN 1679-1061, №. 21, p. 34-65, Jul./Dez., 2016.

http://revista.anphlac.org.br 
1982) e nos explicou como, na ausência de instrumentos adequados para disciplinar o trabalho, o novo agente organizador da produção acabava se tornando um cúmplice da queda da produtividade. Narrou uma situação muito comum nos canaviais:

\begin{abstract}
[A limpeza do] campo de cana tem 3 normas: uma norma é para ervas daninhas escassas (poucas e pequenas), outra é para ervas medianas e outra para pesadas. $\mathrm{O}$ organizador do trabalho, que não está disposto a brigar com 20 trabalhadores e nem tem nenhum instrumento coercitivo em suas mãos para tal briga, tem dois problemas: antes e depois. O primeiro problema é: você é trabalhador e o campo tem ervas daninhas escassas. Eu te digo: "Olha, sua norma é para pouca erva". E você me diz: "Se é para pouca então vou embora. Porque vou ganhar mais no campo denso. Se a norma aqui é tão baixinha não a faço". Mas você tem falta de força de trabalho, precisa que o trabalhador fique. E diz: "Então vou te registrar mediano para que ganhe um pouco mais". É assim que o próprio organizador viola a norma e esse é o problema de antes. Agora vem o problema de depois: já terminou o campo, está limpo. Mas no capitalismo, não te pagam até que o capataz vá ver se está mesmo limpo. Entra com seu cavalo pelo meio do campo, passeia, olha... Porque se ele dá um peso a mais do patrão, o demitem! Há um controle duro do resultado do trabalho. "Quanto limpou?". "Limpei meio hectare". Relata-se o trabalho falado. Não vai lá ver, porque se estiver mau feito teria que brigar com o trabalhador. E voltamos ao princípio: sua função não é brigar com todos os trabalhadores, nenhum dos quais quer trabalhar. Ou querem trabalhar menos e ganhar mais. Essa é a contradição. (VALDÉZ PAZ, 2012)
\end{abstract}

A eliminação do capataz, a promessa do igualitarismo e a economia moral, ao solucionar as principais injustiças sociais e coerções econômicas do capitalismo, acabaram por afrouxar os parafusos do sistema produtivo cubano. ${ }^{21}$ Sendo assim, não apenas o trabalhador voluntário como também o cortador profissional de cana contribuíam para a queda geral da produtividade, trabalhando abaixo de suas capacidades (ROCA, 1976, p. 49).

A criação dos meios técnicos e econômicos necessários para que Cuba reduzisse seu grau de dependência externa exigia, no mínimo, o trabalho disciplinado. Na tentativa de resolver este obstáculo, a revolução cubana abriu dois caminhos: a consciência e a coerção. O trabalho voluntário e o trabalho compulsório foram as duas faces do mesmo processo. Adotados

\footnotetext{
${ }^{21}$ Analisou Mesa-Lago: “A principal razão do absenteísmo reside em que a sociedade socialista não desenvolveu completamente seus próprios métodos para substituir os incentivos e freios do sistema de mercado, que anteriormente eram os que motivavam a produção: salário e medo do desemprego. Há mais dinheiro em circulação que artigos em que gastar. Cada trabalhador sabe que pode viver com o que lhe pagam para trabalhar 15 ou 20 dias ao mês" (1971, p. 104).
}

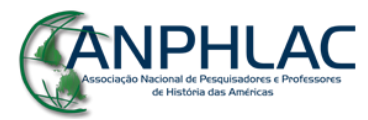

Revista Eletrônica da ANPHLAC, ISSN 1679-1061, Nº 21, p. 34-65, Jul./Dez., 2016.

http://revista.anphlac.org.br 
na tentativa de amenizar a escassez de mão de obra canavieira na safra de 1970, seus efeitos sobre a produção foram contrários ao que se pretendia.

\section{Críticas ao trabalho voluntário}

Desde 1965, na província de Camaguey a safra foi executada com $63 \%$ de trabalho voluntário. A produtividade máxima de um trabalhador voluntário era de 200 arrobas ao dia, ou seja, metade da produtividade média de um profissional. A produtividade dos voluntários urbanos, como os estudantes e os operários da Confederação de Trabalhadores Cubanos (CTC), era baixíssima: 117 e 130 arrobas ao dia respectivamente (ROCA, 1976, p. 46-47). A produtividade nacional da safra de 1970 foi comprometida por este fator. Como sustentou Roca: "É bem possível que o nível geral da produtividade de toda a safra não tenha excedido 200 arrobas por trabalhador/dia" (1976, p. 47). A incapacidade dos voluntários forçou a queda da rentabilidade industrial. Julio Travieso, economista e professor da Universidade de Havana, contou-nos sobre sua experiência no trabalho voluntário nos canaviais:

\footnotetext{
Nós íamos cortar cana e, evidentemente, não tínhamos a destreza para isso, que é muito difícil. A cana deve ser cortada bem abaixo porque a sacarose está embaixo. Se você corta a planta pela metade, faz muito pouco açúcar. Primeiro, tem que cortar as folhas. [...] Parece fácil, mas fazer isso por oito ou dez horas ou mais - por imperativos morais - e sem destreza alguma... Éramos jovens, mas também iam os professores mais velhos. (TRAVIESO, 2012)
}

Não é possível quantificar a responsabilidade do trabalho voluntário sobre a queda dos rendimentos industriais. Contudo, considerando suas dimensões, a hipótese de que o trabalho voluntário paradoxalmente viabilizou a meta de rendimentos agrícolas e inviabilizou a meta de rendimentos industriais é convincente. Se a economia cubana já atravessava uma queda geral da produtividade, o uso do trabalho voluntário aprofundou este problema.

Enfim, como parte do balanço geral do fracasso de 1970, duas ordens de críticas foram elaboradas ao trabalho voluntário cubano. A primeira indica sua irracionalidade econômica e a segunda, sua face coercitiva. Valdés Paz destacou a primeira:

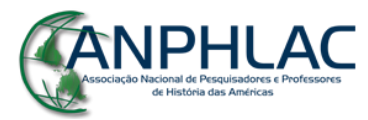

Revista Eletrônica da ANPHLAC, ISSN 1679-1061, №. 21, p. 34-65, Jul./Dez., 2016.

http://revista.anphlac.org.br 
O trabalho voluntário tem duas maneiras de ser medido. Pelos trabalhadores que vão da cidade ao campo, é uma resposta política, uma mobilização ideológica, tem um caráter moral, revela um compromisso revolucionário. Tudo isso, do lado da política. Do lado da economia agrária é um desastre. O trabalho que produz não cobre os custos de transportá-los, abriga-los, dá-los de comer e dotá-los de recursos para trabalhar. Sua produtividade é muito baixa. Não importa que haja um que come um leão cru. Ao lado dele há outro que não faz nada - estou falando em termos estatísticos. Segundo: por sua inexperiência, produzem um dano produtivo que não está quantificado, mas que deve se ter em conta. (VALDÉZ PAZ, 2012)

No contexto de uma economia moral, o descontrole contábil da produção gerava a percepção equivocada de que o trabalho voluntário era isento de custos, como se este representasse nada mais que ganhos coletivos advindos da consciência revolucionária. Devido a esta percepção, o trabalho voluntário contribuía para o aumento do desperdício de recursos produtivos. Como analisou Silverman:

\footnotetext{
Os incentivos morais fomentam amiúde os usos irracionais da mão de obra e do capital, pois os diretores ou gerentes não se sentem obrigados a completar tarefas que poderiam terminar durante a jornada normal de trabalho. Tampouco se sentem obrigados a averiguar as causas da falta de eficiência. Os administradores consideram frequentemente que as horas extras de trabalho ou o trabalho voluntário não representava custos e se sentiam frequentemente perplexos quando lhes perguntavam se não havia ocorrido desperdício de consciência para o cumprimento de suas metas. (SILVERMAN, 1978, p. 178, grifos nossos)
}

Para além da crítica técnico-econômica, Julio Travieso nos manifestou uma crítica política ao trabalho voluntário: a perda de sua capacidade educativa ao longo do tempo e sua dimensão coercitiva. Em Cuba, a prática do trabalho voluntário sistemático na agricultura durou 30 anos, tendo sido fortemente diminuída em 1989. Com o tempo, teria deixado de ser uma mobilização patriótica diante de situações excepcionais, como em 1970, para se tornar uma instituição fixa obrigatória, que além de ser economicamente prejudicial, já não seria capaz de cumprir sua missão ideológica, tendo se convertido em uma rotina esvaziada de sentido. Com

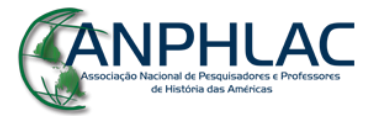

Revista Eletrônica da ANPHLAC, ISSN 1679-1061, №. 21, p. 34-65, Jul./Dez., 2016.

http://revista.anphlac.org.br 
a generalização e institucionalização do trabalho voluntário, seu princípio original foi desvirtuado. ${ }^{22}$

Quando perguntado sobre quais eram as consequências sofridas pelos cubanos que não compareciam ao trabalho voluntário, Travieso respondeu:

\begin{abstract}
Íamos voluntariamente, porque estávamos convencidos de que era necessário, tínhamos consciência de que aquilo era necessário. Eu ia porque queria. A revolução era a revolução e havia que ir. Mas que sucederia se não tivéssemos ido? Teríamos deixado de ser professores, deixado de ser alunos. Seríamos expulsos como professores ou como alunos, e nos chamariam de contrarrevolucionários. Óbvio que você podia uma vez dizer que estava doente. Mas negar-se a ir ao trabalho voluntário acarretava graves sanções morais e materiais. (TRAVIESO, 2012)
\end{abstract}

Ao tornar-se um "dever social”, o trabalho voluntário também respondia pela lógica da coerção. Enquanto o trabalho profissional enfrentava obstáculos relacionados com a disciplina, o trabalho voluntário se tornou, simultaneamente, uma mobilização educativa e uma atividade compulsória. Na percepção do próprio Guevara, o trabalho voluntário não estava isento da violência. A dimensão coercitiva era inversamente proporcional ao desenvolvimento da consciência revolucionária. Em sua carta a Quijano, Guevara escreveu:

Fazemos todo o possível para dar ao trabalho esta nova categoria de dever social e uni-lo ao desenvolvimento da técnica, por um lado, o que dará condições para uma maior liberdade, e ao trabalho voluntário por outro, baseado na apreciação marxista de que o homem realmente alcança sua plena condição humana quando produz sem a compulsão da necessidade física de vender-se como mercadoria. Claro que ainda há aspectos coativos no trabalho, ainda quando seja voluntário; o homem não transformou toda a coerção que o rodeia em reflexo condicionado de natureza social e ainda produz, em muitos casos, sob a pressão do meio (compulsão moral, o chama Fidel). (GUEVARA, 2011, p. 232, grifos nossos)

$\mathrm{Na}$ falta das recompensas materiais, a economia moral encontrou métodos não monetários de coerção para garantir a disciplina do trabalhador, nos casos em que a consciência era "insuficiente". Uma das formas rotineiras criadas para constranger moralmente o

\footnotetext{
${ }^{22} \mathrm{Na}$ análise de Travieso, "Havia um antecedente: os sábados voluntários de Lênin, que eram meio sábado. Era uma vez ao ano, sei lá eu. Aqui em Cuba, uma vez ao mês, mais 45 dias ao ano. (...) E ao final a produtividade era baixíssima. Nem sempre era cortar cana, eram atividades totalmente absurdas, que não tinham sentido, se foi deformando" (2012).
}

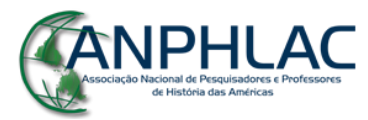

Revista Eletrônica da ANPHLAC, ISSN 1679-1061, №. 21, p. 34-65, Jul./Dez., 2016.

http://revista.anphlac.org.br 
trabalhador pouco produtivo era escrever seu nome em um painel público na unidade de produção, de modo a responsabilizá-lo oficialmente pelo eventual não cumprimento das metas (MESA-LAGO, 1971, p. 82). As organizações de massas como a União de Jovens Comunistas (UJC), a CTC e a Federação de Mulheres de Cuba (FMC) realizavam uma forte pressão para recrutar trabalhadores voluntários e, como nos explicou Travieso, negar esse recrutamento poderia significar uma deterioração dos vínculos afetivos e profissionais dos indivíduos com a sociedade, num processo de desmoralização e isolamento. Diante desse tipo de ameaça, o trabalho voluntário passou a ser praticado como trabalho gratuito obrigatório. Como analisou Silverman:

Se os incentivos morais falham, então haverá que fazer frente a execrável necessidade de coerção. Ainda que o compromisso da população cubana com a revolução tenha reduzido a necessidade de recorrer à força, a consciência é também recurso escasso e um dos problemas fundamentais de Cuba pode ser o de usá-la eficientemente. (SILVERMAN, 1978, p. 175, grifos nossos)

Diante do excessivo otimismo do governo revolucionário com a safra, em um contexto em que a contabilidade social já estava descontrolada, teria havido também, em alguns casos, a quebra de confiança entre os trabalhadores e os organismos de trabalho no que diz respeito ao cumprimento das metas. Na economia moral, quando o trabalhador não acredita na viabilidade de execução das metas lançadas pelas autoridades, o impacto negativo sobre a produção é mais intenso, já que é sobre esta relação de confiança entre trabalhador e direção revolucionária que se assenta a consciência. Afinal, se é o cumprimento das metas que regulava o incentivo ou castigo moral de cada trabalhador, saber de antemão que os planos eram irrealizáveis criava um compreensivel desconforto entre os trabalhadores, que seriam punidos por erros que não cometeram. Uma mínima quebra de honestidade nas relações de produção, os pequenos gestos de burla do sistema facilitados pelo descontrole contábil e a pressão moral sem recompensas materiais, na avaliação de Silverman, teriam gerado uma "cínica desconfiança que debilita a identificação do trabalhador com o sistema, ingrediente essencial do modelo" (1978, p. 176).

A necessidade de criar instrumentos de disciplina no trabalho gerou, posteriormente à safra, em 1971, a lei contra a vadiagem, através da qual todos os homens aptos ao trabalho,

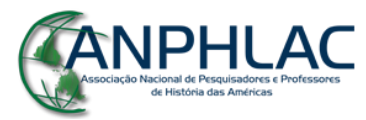

Revista Eletrônica da ANPHLAC, ISSN 1679-1061, №. 21, p. 34-65, Jul./Dez., 2016.

http://revista.anphlac.org.br 
entre 17 e 60 anos, que se ausentassem de seus postos, teriam que trabalhar sob a vigilância de outro trabalhador ou das organizações de massas e, em casos extremos, iriam para "centros de reabilitação" durante no máximo um ano (SILVERMAN, 1978, p. 180). Eram centros de trabalho forçado. Como definiu Alberto Mora, defensor dos incentivos materiais, a economia moral significou: "substituição da motivação do lucro pela do poder" (MORA apud SILVERMAN, 1978, p. 184). Por isso, a face gêmea do trabalho voluntário teria sido a militarização da safra e o trabalho compulsório das "reabilitações".

\section{A militarização do trabalho}

Desde 1963, os cidadãos recrutados para o serviço militar obrigatório eram levados ao trabalho agrícola nas Unidades Militares de Apoio à Produção ${ }^{23}$. Desde então, o soldado já era empregado como braço para colheita. Mas na safra de 1970, as Forças Armadas participaram da produção de modo sem precedentes, seja executando diretamente o corte de cana, seja controlando o trabalho dos centros de reabilitação, para onde iam os "desobedientes" e os "contrarrevolucionários" durante a ofensiva. Para conter a indisciplina laboral, convinha criar um clima de permanente vigilância. Uma Comissão Disciplinar Administrativa (Codiad) investigava e julgava funcionários acusados de "crimes" e os condenados eram enviados às fazendas de trabalho, organizadas pelo Ministério do Interior (PERICÁS, 2004, p. 179).

Nesse sentido, uma das principais consequências da safra de 1970 na organização da agricultura foi o fim da relativa autonomia produtiva adotada em 1963, como parte da proposta de Carlos Rafael Rodríguez. A tentativa de encontrar uma justa medida entre planejamento centralizado e democracia na unidade de produção agrária fora suplantada pelas exigências objetivas da safra e pela centralização ideológica que caracterizou a experiência da ofensiva. Não poderia haver espaço para iniciativas locais autônomas, pois todos os recursos produtivos da ilha precisavam se concentrar nas 10 milhões, como garantia de que o "grande salto" da estratégia turnpike fosse cumprido.

23 Segundo Mesa-Lago (1971), os soldados eram divididos em grupos de acordo com seu compromisso revolucionário e aqueles que não estivessem "plenamente integrados" eram preferidos para o trabalho manual.

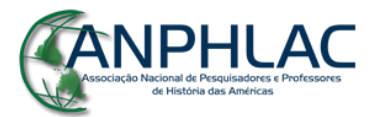

Revista Eletrônica da ANPHLAC, ISSN 1679-1061, No. 21, p. 34-65, Jul./Dez., 2016.

http://revista.anphlac.org.br 
A militarização do trabalho centralizou a agropecuária como em uma operação de guerra. Na ausência de ferramentas monetárias e diante da "escassez de consciência", o processo de descentralização foi interrompido. Desde 1965 foi criado um destacamento especial de dirigentes do Partido para supervisionar a safra de 1970 - o Setor Safra. Conforme avançava a ofensiva, as decisões agrícolas passaram a ser cada vez mais centralizadas nesta equipe, até que, em 1968, o Setor Safra foi substituído pelos postos de mando, quartéis generais do exército que fiscalizavam o trabalho agrícola (SILVERMAN, 1978, p. 178-9; VALDÉS PAZ, 2009, p. $41)$.

Em algumas granjas, então, o exército passou a ocupar a função de agente disciplinador do trabalho, elo que se encontrava debilitado após a eliminação do capataz capitalista. Fiscalizava-se não apenas o trabalho manual, mas também o administrativo, considerando a inevitável cumplicidade do administrador com a queda da produtividade. "A consequência desse modelo", definiu Valdés Paz em 2010, "seria uma restrição à democracia, pois as decisões são tomadas e não há discussão" (VALDÉS PAZ et al., 2012, p. 76). A duração dos postos de mando foi curta, mas representativa da nova contradição entre emancipação social e imperativos desenvolvimentistas no decorrer de uma estratégia sacrificante. Ao final deste enervante processo de perseguição do impossível, os dirigentes cubanos produziram sua autocrítica.

\section{Autocrítica da safra de 1970}

Se Fidel Castro foi um dos maiores responsáveis pelo esforço das 10 milhões, ao desenhar uma meta inviável mesmo depois de ter sido alertado por especialistas cubanos e estrangeiros, considerados "céticos" ou "pessimistas", o próprio dirigente assumiu publicamente a responsabilidade pelos prejuízos de tal esforço. ${ }^{24}$ Em 19 de maio de 1970, dois meses antes do fim da safra, Fidel declarou oficialmente que não seria possível atingir a meta.

\footnotetext{
${ }^{24}$ Barkin sustentou: "a falta de cumprimento das metas de produção se fizeram evidentes em todos os setores da economia muito antes dos fracassos mais difundidos e analisados pelo Primeiro Ministro em seu famoso discurso de 26 de julho de 1970" (1978, p. 132). Os alertas foram diretamente transmitidos ao governo. René Dumont sugeriu a Fidel, em 1967, que a meta de 10 milhões fosse adiada para 1975 (Dumont, 1970, p. 143). Gutelman aconselhou, em 1968, que fosse transferida para 1972 (1975, p. 274).
}

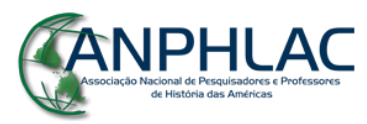

Revista Eletrônica da ANPHLAC, ISSN 1679-1061, No. 21, p. 34-65, Jul./Dez., 2016.

http://revista.anphlac.org.br 
Ao mesmo tempo, buscou acertar suas contas com o povo cubano, enfatizando a transparência da direção sobre o tema:

Se vocês querem que eu lhes diga com toda a clareza a situação, é que simplesmente não faremos 10 milhões. Simplesmente. Não vou andar com rodeios para dizê-lo. Creio que para mim, igual para qualquer outro cubano em um grau elevado, significa realmente algo muito duro. [...]. Agora, nunca se enganou ao povo, nem se enganará nesse momento, em que ainda resta muita cana por cortar e muito açúcar por produzir; eu sempre disse: 'o dia e a hora em que, de acordo com a situação, tenhamos todos os cálculos, saibamos que não alcançaremos - pelas razões que sejam - as 10 milhões, o diremos ao povo'. Não manteremos uma ilusão até a última hora. Não a manteremos porque não seria honesto. Não é por esses meios que temos que mobilizar o povo para realizar o esforço e não o faremos jamais! (CASTRO, 19 mai., 1970)

Na sua autocrítica Fidel analisou que, apesar das distorções estruturais e dos prejuízos, a safra de 1970 produziu um recorde: a maior produção da história da ilha e um crescimento de 90\% em relação a 1969 (4 milhões de toneladas a mais). Com isso, atingiu-se a maior média histórica de seis em seis anos (1964-1970) (ROCA, 1976, p. 13). As 8,5 milhões representariam, na avaliação de Fidel, uma derrota moral e uma vitória econômica (CASTRO, 19 mai., 1970). Diante disso, um dos erros apontados foi justamente o subjetivismo dos prognósticos da direção revolucionária. Em 26 de julho de 1970, Fidel discursou:

Em primeiro lugar, vamos apontar em todos estes problemas a responsabilidade de todos nós e a minha em particular. De modo algum, pretendo distribuir responsabilidades que pense não me pertencerem também a mim e a toda a direção da Revolução. [...] Creio que nós, os dirigentes desta Revolução, saímos demasiadamente caros com o nosso processo de aprendizagem. E desgraçadamente, o nosso problema [...] é, antes de tudo, a herança da nossa própria ignorância. (CASTRO, 1980, p. 35, grifos nossos)

Assim, o governo cubano reconheceu oficialmente o erro de subestimar as dificuldades, minimizar os desafios e propagar um otimismo sem base material (CASTRO, 1980, p. 41). A origem subjetiva da meta de 10 milhões havia sido um dos equívocos mais criticados pelos especialistas internacionais. Por um lado, haveria um excessivo otimismo dos dirigentes com as capacidades produtivas da ilha. Por outro, haveria também uma excessiva confiança na infalibilidade humana, como se o "homem novo" já pudesse ser construído a partir da vontade

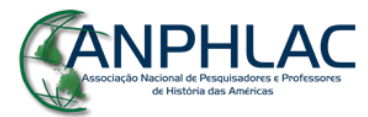

Revista Eletrônica da ANPHLAC, ISSN 1679-1061, №. 21, p. 34-65, Jul./Dez., 2016.

http://revista.anphlac.org.br 
política, desconsiderando a necessidade histórica de uma profunda transformação da cultura (BARKIN, 1978, p. 133, 137).

Outro erro apontado por Fidel foi o uso excessivo do trabalho voluntário, que deslocou dezenas de milhares de estudantes atrasando a formação de técnicos superiores. Os estudantes de ensino técnico dedicavam três a quatro meses por ano ao corte da cana nos mutirões voluntários, procrastinando sua diplomação e perpetuando a escassez de mão de obra qualificada, que afinal constituía uma das dificuldades mais prementes do país (CASTRO, 1980, p. 18). "Quando falávamos das dez milhões, o problema era de braços. Diria que neste momento temos a frente um problema de cérebros, um problema de inteligência", sintetizou Fidel em 26 de julho de 1970 (1980, p. 56).

É relevante também a crítica dos agricultores pequenos à ofensiva revolucionária. Barrios analisou que tanto os líderes do Setor Safra quanto os administradores locais subestimaram a Associação Nacional de Agricultores Pequenos (ANAP) como organismo dirigente e desprezaram a produção camponesa. A safra teria não apenas gerado situações de violência contra o campesinato ao longo da ofensiva revolucionária, mas também prejudicado a produção deste segmento da estrutura agrária:

\footnotetext{
A incidência negativa que sobre outros importantes ramos da economia nacional ocasionou a concentração de recursos materiais e humanos em função da safra, também se refletiu no setor camponês, praticamente em todas as linhas da agricultura não canavieira: viandas, hortaliças, grãos e na produção de tabaco [...]. Todas estas causas apontadas, unidas à subestimação do papel da ANAP que se havia impregnado em muitos dirigentes e funcionários administrativos, trouxeram como consequência a já mencionada baixa na produção não canavieira do setor camponês. (BARRIOS, 1987, p. 85)
}

Outro componente da autocrítica, correlato a este, foi também elencado por Carlos Rafael Rodríguez: o excessivo "administrativismo" do partido no período da safra de 1970. Ao se empenhar para alcançar as 10 milhões, o Partido Comunista de Cuba teria, em sua opinião, abandonado temporariamente suas tarefas políticas de convencimento, esclarecimento e representação da população, para assumir funções burocráticas e técnicas que não lhes correspondiam (RODRÍGUEZ, 1983, p. 478).

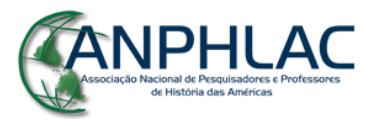

Revista Eletrônica da ANPHLAC, ISSN 1679-1061, Nº. 21, p. 34-65, Jul./Dez., 2016.

http://revista.anphlac.org.br 
O fracasso da safra de 1970, enfim, revelou alguns dos mais desafiadores limites da construção do socialismo na periferia do capitalismo: a construção de novas relações sociais de produção em situação de dependência tecnológica. No rescaldo de erros, excessos e boas intenções, como ensinou Florestan Fernandes, "um povo não pode livrar-se, em pouco mais de um decênio, do fardo de uma herança pesada, deixada por cinco séculos de colonialismo e neocolonialismo" (2007, p. 197).

\section{Considerações finais}

Júlio Diaz Vázquez contou que “entre 1971 e 1975, um especialista soviético que visitou a ilha disse que, em termos teóricos, Cuba havia vivido uma etapa muito similar ao comunismo de guerra da URSS" (VALDÉS PAZ et al., 2012, p. 72). O esforço da safra de 1970 gerou uma série de consequências negativas para a sociedade cubana, entre elas, a perda relativa de soberania nacional nas decisões sobre organização da economia.

O laboratório de estratégias da década de 1960 fechou suas portas com o enfraquecimento relativo das "vantagens geopolíticas" cubanas, condicionando seu ingresso definitivo ao COMECON ${ }^{25}$ em 1972. A partir de então, adotou-se uma sistemática importação de modelos econômicos, com redução das margens de decisão interna e aplicação de manuais soviéticos de planejamento e gestão. Durante as duas décadas seguintes, Cuba ajustou sua economia para a integração especializada no bloco, perpetuando excessivamente seu caráter agroexportador e monoprodutor, adiando o projeto estratégico de diversificação. Se o sentido sincrônico de tal decisão pode ser justificado pela falta de outras opções imediatas no contexto de uma "revolução insertada"26, diacronicamente, a crise da estratégia turnpike instalou uma ausência de horizontes para a diversificação econômica e o agravamento da dependência externa. As consequências atrozes vividas pelos cubanos durante o chamado "período especial" nos anos 1990 são resultado direto desta ausência.

\footnotetext{
${ }^{25}$ Council for Mutual Economic Assistance (Conselho para Assistência Econômica Mútua), instituição multilateral que integrava as economias centralmente planificadas do bloco soviético.

${ }^{26}$ Definido pelo salvadorenho-palestino Shafick Handal, o conceito nos foi apresentado por Regalado (2012). A revolução insertada explica o isolamento da ilha no continente latino-americano depois da onda de golpes civilmilitares dos anos 1950 a 1980, caracterizando a falta de alternativas de alianças para além do bloco soviético.
}

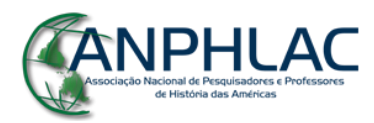

Revista Eletrônica da ANPHLAC, ISSN 1679-1061, №. 21, p. 34-65, Jul./Dez., 2016.

http://revista.anphlac.org.br 
A safra de 1970 também ensinou à direção revolucionária cubana que o entusiasmo, a vontade política, o esforço individual e a consciência não poderiam substituir o desenvolvimento das forças produtivas (SILVERMAN, 1978, p. 183). O "grande salto" do desenvolvimento se frustrou, impondo a necessidade de correções. Fragilizou-se o modelo cubano de "socialismo com traços nacionais" (VALDÉS PAZ, 2012), dando origem à incorporação dos modelos soviéticos. Nesse sentido, 1970 representa uma inflexão importantíssima da história cubana, marcada pela experiência de que a consciência, além de ser um "recurso escasso", não foi capaz de garantir a alavancagem necessária para superação da monocultura.

No Primeiro Congresso do Partido Comunista de Cuba em 1976, Fidel fez uma crítica da economia moral e da desvinculação entre salário e trabalho, apontada como uma das principais causas do absenteísmo e da indisciplina laboral. Avaliou-se então que, apesar dos incentivos morais serem um oxigênio ideológico fundamental, abandonar completamente os incentivos materiais teria sido uma opção equivocada e precipitada durante os anos da ofensiva revolucionária (CEPAL, 1980, p. 22).

A insuficiência da alavanca econômica da consciência, sobre a qual se depositaram tantas expectativas, deu origem a novas relações sociais de coerção, seja pela sutileza de um "trabalho voluntário" que se praticava em alguns casos como trabalho gratuito obrigatório, seja pela militarização da safra, pela centralização das decisões de produção e pelo atropelamento das margens de autonomia relativa do campesinato. Enfim, em Cuba, a contradição entre produtividade e emancipação no socialismo periférico originou diferentes estratégias de disciplinamento laboral, ora focadas na potencial solidariedade coletivista dos trabalhadores, ora na mais direta coerção. Os historiadores comprometidos com a crítica dialética ao capitalismo encontram nesse terreno um importante problema de investigação.

\section{Referências Bibliográficas}

AMIN, S. O Desenvolvimento Desigual - ensaio sobre as formações sociais do capitalismo periférico. $1^{\text {a }}$ ed. Rio de Janeiro: Forense-Universitária, 1976.

ARANDA, S. La revolución agraria en Cuba. $1^{\text {a }}$ ed. México: Siglo XXI, 1968.

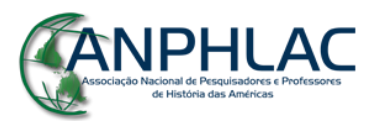

Revista Eletrônica da ANPHLAC, ISSN 1679-1061, №. 21, p. 34-65, Jul./Dez., 2016.

http://revista.anphlac.org.br 
VASCONCELOS, J. S. Acumulação socialista originária e o debate econômico da transição em Cuba. Leituras de Economia Política (UNICAMP), n. 19, 2011.

. Acumulação socialista em Cuba: a herança da plantation na reforma agrária (19591970). Dissertação de Mestrado, IE/UNICAMP, 2013.

Propriedade coletiva em debate: caminhos da revolução agrária em Cuba. Revista NERA (UNESP), v. 27, 2015.

BARRIOS, A. M. La ANAP: 25 años de trabajo. $1^{\text {a }}$ ed. La Habana: Editora Política, 1987.

BARKIN, D.; MANITZAS, N. (Org.). Cuba: Camino Abierto. $1^{\text {a }}$ ed. México: Siglo XXI, 1978.

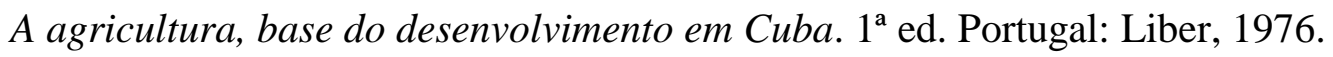

CASTRO, F. Autocrítica. São Paulo: Centro Editorial Latino Americano, 1980.

. Discurso de Fidel Castro na comemoração do VI aniversário dos Comitês de Defesa da Revolução. Praça da Revolução, Havana, 28 set., 1966. Acesso em 15 jan., 2016: http://www.cuba.cu/gobierno/discursos/1966/esp/f280966e.html

Discurso de Fidel Castro no ato de recebimento dos onze pescadores sequestrados, em frente à Embaixada dos Estados Unidos. Havana, 19 mai., 1970. Acesso em 15 jan., 2016: http://www.cuba.cu/gobierno/discursos/1970/esp/f190570e.html

Discurso de Fidel Castro no ato central do Primeiro de Maio. Havana, $1^{\circ}$ mai., 1971. Acesso em 15 jan., 2016: http://www.cuba.cu/gobierno/discursos/1971/esp/f010571e.html

Discurso de Fidel Castro na comemoração do XX aniversário do ataque ao quartel Moncada. Santiago de Cuba, 26 jul., 1973. Acesso em 15 jan., 2016: http://www.cuba.cu/gobierno/discursos/1973/esp/f260773e.html

CEPAL. Cuba: estilo de desarrollo y políticas sociales. Ciudad de México, D. F.: Siglo Veintiuno, 1980.

CHONCHOL, J. La reforma agraria cubana - realizaciones y perspectivas. Informe Final de Misión el Gobierno Cubano. La Habana: FAO, 1961.

DUMONT, R. Cuba: socialism and development. $1^{\text {a }}$ ed. New York: Grove, 1970.

EDQUIST, C. Capitalism, Socialism and Technology - a comparative study of Cuba and Jamaica. $1^{\text {a }}$ ed. New Jersey: Zed, 1985.

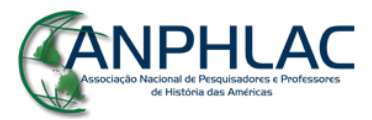

Revista Eletrônica da ANPHLAC, ISSN 1679-1061, №. 21, p. 34-65, Jul./Dez., 2016.

http://revista.anphlac.org.br 
FAO. Informe al Gobierno de Cuba sobre los antecedentes del Plan Perspectivo Pesquero, 1966-1970. Basado en el trabajo de Manuel Achurra Larraín, Asesor Pesquero de la FAO. Rep. FAO/UNDP(TA), (TA 2268), 1966.

FERNANDES, F. Da guerrilha ao socialismo - A revolução cubana. $1^{\text {a }}$ ed. São Paulo: Expressão Popular, 2007.

FURTADO, C. A Superação do Subdesenvolvimento. Revista Economia e Sociedade. n. 3. Campinas: IE/UNICAMP, dez., 1994.

Pequena Introdução ao Desenvolvimento. $2^{\mathrm{a}}$ ed. São Paulo: Ed. Nacional, 1981.

GUEVARA, E. El socialismo y el hombre en Cuba (1965). In: Che Guevara Presente: Antología Mínima. $1^{\mathrm{a}}$ ed. La Habana: Editorial de Ciencias Sociales/Ocean Sur/Centro de Estudios Che Guevara, 2011, p. 224-239.

Textos Econômicos para a transformação do socialismo. $1^{a}$ ed. São Paulo: Edições Populares, 1982. 2006.

. El Gran Debate sobre la economía cubana 1963-1964. $1^{\text {a }}$ ed. New York: Ocean Press,

GUTELMAN, M. A agricultura socializada em Cuba. $1^{\text {a }}$ ed. Lisboa: Prelo, 1975.

JUCEPLAN. Boletín Estadístico de 1970. La Habana: JUCEPLAN, 1971.

LÊNIN, V. Uma Grande Iniciativa. In: Obras Escolhidas. v. 3. São Paulo: Alfa-ômega, 1980.

LUCAS, M. R. De Taylor a Stakhanov: utopias e dilemas marxistas em torno da racionalização do trabalho. Tese de Doutorado, IFCH/UNICAMP, 2015.

MESA-LAGO, C. Cuba: teoría y práctica de los incentivos. Latin American Studies. $\mathrm{n}^{\circ}$ 7, Occasional Papers, June/1971.

MARX, K; ENGELS, F. A Ideologia Alemã. $1^{\text {a }}$ ed. São Paulo: Boitempo, 2007.

MARX, K. O Capital. Crítica da Economia Política. Livro I, O Processo de Produção do Capital. $23^{\mathrm{a}}$ ed., v. 1 e 2, Rio de Janeiro: Civilização Brasileira, 2006.

Crítica ao Programa de Gotha. In: ANTUNES, R. (Org.). A Dialética do Trabalho. $4^{\mathrm{a}}$ ed., São Paulo: Expressão Popular, 2005.

PERICÁS, L. B. Che Guevara e o debate econômico em Cuba. $1^{\text {a }}$ ed. São Paulo: Xamã, 2004.

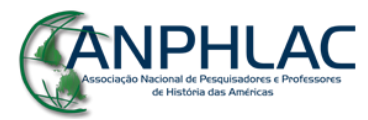

Revista Eletrônica da ANPHLAC, ISSN 1679-1061, No . 21, p. 34-65, Jul./Dez., 2016.

http://revista.anphlac.org.br 
ROCA, S. Cuban economic policy and ideology: the ten million ton sugar harvest. In: International Studies Series, $n^{\circ} 4 ., 1^{\mathrm{a}}$ ed., London: Sage Publications, 1976.

RODRÍGUEZ, C. R. Letra con Filo. Tomos I y II. $1^{\text {a }}$ ed. La Habana: Editorial de Ciencias Sociales, 1983.

SAMPAIO JUNIOR, P. A. O impasse da 'formação nacional'. In: FIORI, José Luis (Org.). Estados e moedas no desenvolvimento das nações. $1^{\mathrm{a}}$ ed. Petrópolis: Vozes, 2000.

SILVERMAN, B. Organización económica y conciencia social: algunos dilemas. In: BARKIN, D.; MANITZAS, N. R. (Orgs.). Cuba: Camino Abierto. $1^{\text {a }}$ ed., Ciudad de México, D.F.: Siglo XXI, 1978.

VALDÉS PAZ, J.; DÍAZ VÁZQUEZ, J. A.; DÍAZ, S. La Zafra de los diez millones: una mirada retrospectiva. Revista Temas, n.72, La Habana, Oct-Dec/2012.

VALDÉS PAZ, J. Los Procesos de Organización Agraria en Cuba, 1959-2006. $1^{\mathrm{a}}$ ed., La Habana: Fundación Antonio Nuñez Jiménez, 2009.

\section{Entrevistas}

BARKIN, David. Entrevista com David Barkin [12 nov., 2011]. Entrevistadora: Joana Salém Vasconcelos. Gravação digital. Cidade do México, 2011.

REGALADO, Roberto. Entrevista com Roberto Regalado [13 jul., 2012]. Entrevistadora: Joana Salém Vasconcelos. Gravação digital. Havana, 2012.

VALDÉS PAZ, Juan. Entrevista com Juan Valdés Paz [16 jul., 2012]. Entrevistadora: Joana Salém Vasconcelos. Gravação digital. Havana, 2012.

TRAVIESO, Julio. Entrevista com Julio Travieso [17 jul., 2012]. Entrevistadora: Joana Salém Vasconcelos. Gravação digital. Havana, 2012.

\section{GANPHLAC}

